\title{
Efektivitas Reformasi Birokrasi Pada Area Perubahan Sumber Daya Manusia (SDM) Aparatur Di Pemerintah Kota Payakumbuh Provinsi Sumatera Barat
}

\author{
${ }^{1}$ Sandra Vika, ${ }^{2}$ Sujianto \\ ${ }^{12}$ Program Studi Pascasarjana Ilmu Administrasi Publik Universitas Riau \\ e-mail : sujianto@lecturer.unri.ac.id
}

\begin{abstract}
Abstrak
Penelitian ini bertujuan untuk mengetahui pengimplementasian kebijakan reformasi birokrasi di pemerintah kota Payakumbuh khususnya area perubahan SDM Aparaturserta untuk mengetahui kendala yang dirasakan oleh SDM Aparatur dalam melaksanakan kebijakan ini. Berdasarkan PP No. 81 tahun 2010 tentang Grand desain Reformasi birokrasi untuk area perubahan SDM aparatur target yang ingin dicapai adalah berupa 7 (tujuh) indikatorprofil aparatur yakni SDM aparatur yang berintegritas, Netral, kompeten, capable, profesional, berkinerja tinggi dan sejahtera. Adapun ke 7 (tujuh)capaian tersebut menjadi target dengan diimplementasikannya rencana aksi reformasi birokrasi yang sudah ditetapkan. Jenis penelitians ini yaitu pendekatan deskriptif kualitatif dengan metode wawancara langsung ke informan dan analisis data bersifat kualitatif. Pengumpulan data primer melalui wawancara langsung ke SDM aparatur yang ada di kota Payakumbuh dan dikarenakan situasi pandemi korona yang menyarankan untuk mengurangi tatap muka langsung maka wawancara dan penggalian informasi serta data juga dilakukan via media elektronik seperti media sosial whatsapp, instagram, facebook dan juga berbicara langsung via telephone. Metode analisis data menggunakan penggabungan informasi dan pencocokan untuk menguji keakuratan data. Hasil penelitian menunjukkan bahwa SDM Aparatur pada pemerintah Kota Payakumbuh menjalankan instruksi berkenaan dengan reformasi birokrasi khususnya pada area perubahan SDM aparatur sesuai atau mengikuti arahan pimpinan dan pemimpin saat ini mengarahkan dan menginstruksikan dengan sangat baik segala program dan rencana aksi yang telah ditetapkan sehingga menghasilkan suatu aksi nyata yang membawa nama baik berupa berbagai prestasi dan penghargaan bagi Kota Payakumbuh. Meskipun masih ada kendala berupa adanya SDM aparatur yang tidak memahami tugas dan tanggung jawab secara akurat tetapi itu terjadi hanya di level staf yang tingkat pendidikan rendah sedangkan pimpinan diatasnya dapat mengakomodirnya dengan baik dan pada SDM aparatur level menengah yang kurang memahami pekerjaan dengan baik terjadi hanya pada mereka dengan usia yang hampir memasuki masa purna tugas. Namun secara umum SDM Aparatur dapat bekerja sama menyelesaikan tugas dan tanggung jawab sesuai bidang masing masing organisasi perangkat Daerah (OPD) tempat mereka bekerja.
\end{abstract}

Kata kunci: Efektivitas,Reformasi Birokrasi, Sumber Daya Manusia (SDM), Aparatur Pemerintah

\begin{abstract}
This Research aims to identify and analyze the human resources of Payakumbuh government officials in understanding and implementing the bureaucratic reform policies implemented by the government and to find out the obstacles felt by human resources in implementing this policy. Bureaucratic reform in the area of human resource change wants results in the form of 7 (seven) indicators of target / achievement of human resources, namely personnel with integrity, neutral, competent, empowered, professional, high-performance and prosperous. The 7 (seven) achievements have become targets with the implementation of the bureaucratic reform action plan that has been determined. This type of research is a qualitative descriptive approach with direct interviews to informants and qualitative data analysis. Primary data collection through direct interviews with human resources in the city of Payakumbuh and due to the corona pandemic situation which suggests reducing direct face-to-face interviews, interviews and extracting information and data are also carried out through electronic media such as social media WhatsApp, Instagram, Facebook and also speaking directly by phone. The data analysis method uses information combining and matching to test the accuracy of the data. The results showed that the Human Resources Apparatus at the Payakumbuh City government carried out instructions with regard to bureaucratic
\end{abstract}


reform, especially in the area of changing human resource personnel according to or following the direction of current leaders and leaders very well directing and instructing all programs and action plans that have been set to produce real action which brings a good name in the form of various achievements and awards for the City of Payakumbuh. Although there are still obstacles in the form of human resource personnel who do not understand their duties and responsibilities accurately, this occurs only at the staff level with a low level of education while the leadership above can accommodate it properly and for middle-level human resources who do not understand their work properly occurs only at those who are nearing retirement age. However, in general the human resources of the apparatus can work together to complete the tasks and responsibilities according to the respective fields of the Regional apparatus organization (OPD) where they work.

\section{Keywords: Effectivity,Bureaucracy reform, Human resources and Aparatus government}

\section{PENDAHULUAN}

Reformasi birokrasi tidak hanya di pemerintahan pusat saja, pada level pemerintah daerahpun reformasi birokrasi saat ini secara serentak dan bertahap wajib dilakukan disesuaikan dengan kondisi pemerintah daerahnya. Masing-masing pemerintah daerah melakukan upaya perbaikan kearah lebih baik mengikuti instruksi nasional. Dengan dikeluarkannya regulasi mengenai reformasi birokrasi, pemerintah daerah mulai bahu membahu meningkatkan segala sesuatu yang merupakan indikator pengungkit keberhasilan Reformasi Birokrasi.

Kota Payakumbuh yang merupakan bagian dari Propinsi Sumatera Barat juga menjawab arahan pemerintah pusat dengan mengeluarkan roadmap reformasi birokrasi Kota Payakumbuh. Kota Payakumbuh yang pada saat ini memiliki 31 Organisasi Perangkat Daerah dengan 3.023 orang ASN didalamnya berdasarkan data dari BKPSDM pada bulan Juni tahun 2020 (lihat tabel.1) sedang melaksanakan roadmap reformasi birokrasi 2016 - 2020 yang telah diagendakan pada akhir tahun 2015 lalu. Saat ini sudah berada pada tahap akhir dari Road map yang direncanakan. Setiap OPD kini sedang mengevaluasi program yang telah direncanakan.

Permasalahan birokrasi pemerintah daerah kota Payakumbuh yang bersumber dari hasil evaluasi Kementrian Pendayagunaan Aparatur Negara Dan Reformasi Birokrasi tahun 2019 sebagai berikut :

1. Penataan peraturan perundang undangan belum dilaksanakan secara optimal, khususnya identifikasi dan harmonisasi peraturan perundang undangan

2. Kelembagaan yang ada saat ini belum mengacu pada proses bisnis dalam rangka mewujudkan kinerja yang ditetapkan dalam RPJMD

3. Penataan sistem manajemen SDM belum berjalan secara maksimal, misalnya belum dilakukan assessment terhadap seluruh pegawai, belum adanya sistem perencanaan pengembangan kapasitas SDM yang terpadu dan belum adanya penetapan kinerja individu yang selaras dengan kinerja organisasi

4. Pemerintah Kota Payakumbuh di tahun 2019 belum berhasil membangun unit kerja zona integritas wilayah bebas dari korupsi di unit unit kerja strategis dan melakukan pelayanan langsung ke masyarakat

5. Sistem pengawasan belum berjalan secara optimal dilihat belum adanya kebijakan whistleblowing system (WBS) dan kebijakan benturan kepentingan.

6. Survey tentang jabatan terhadap 150 pegawai menunjukkan hanya $25 \%$ yang memahami tugas dan fungsi yang harus dilaksanakan dan ukuran keberhasilannya, $67 \%$ memahami tugas dan fungsi yang harus dilaksanakan namun tidak memahami ukuran keberhasilannya dan sisanya sebanyak $8 \%$ tidak memahami tugas dan fungsi yang harus dilaksanakan serta ukuran keberhasilannya. 
7. Survey internal terhadap integritas organisasi menunjukkan indek 3,41 umtuk tahun 2019 skala 4 (ideal 3,60 berdasarkan permenpan RB nomor 52 tahun 2014)

8. Survei eksternal terhadap masyarakat yang menerima layanan pemerintah kota Payakumbuh mendapatkan indeks 3,49 untuk tahun 2019 skala 4 yang artinya masih ada kesenjangan atau gap antara harapan penerima layanan dengan realitas kondisi layanan prima

9. Survei persepsi korupsi menunjukkan indeks 3,64 dalam skala 4, menurut evaluasi dari kemnpan masih perlu ditingkatkan.

(sumber : Evaluasi KemenpanRB 2019)

Pelaksanaan reformasi birokrasi di Kota Payakumbuh merupakan sebuah keharusan yang dilakukan dengan tujuan untuk memperbaiki birokrasi dari waktu ke waktu, sehingga birokrasi Pemerintah Kota Payakumbuh memiliki kemampuan untuk memberikan pelayanan yang berkualitas kepada masyarakat, menghilangkan praktek KKN secara menyeluruh di semua unit kerja dan bidang kerja pemerintah daerah. Perencanaanreformasi birokrasi Pemerintah Kota Payakumbuh yang terdapat pada road map reformasi birokrasi 2016 - 2020 telah diselaraskan dengan RPJM Kota Payakumbuh dan sejalan dengan visi pembangunan nasional (roadmap reformasi birokrasi 2016 - 2020).Delapan area perubahan yang tertuang dalam Grand Desain Reformasi Birokrasi nasional (lihat gambar 3) juga menjadi pedoman bagi pemerintah daerah Kota Payakumbuh dalam menyusun rencana reformasi birokrasi di level instansional.

Kunci sukses penentu keberhasilan Reformasi Birokrasi seperti termuat dalam buku Toha, 2008:113 yang mengatakan bahwa lancarnya penyelenggaraan pemerintahan suatu Negara pelaksanaan pembangunannya tergantung terutama dari kesempurnaan aparatur Negara ini oleh karena itu SDM aparaturnya diharapkan dapat menerima dan melaksanakan kebijakan tersebut. Namun belum ada suatu riset yang mendalam mengenai hal ini.Sebuah penelitian yang dibutuhkan untuk menjawab pertanyaan tentang kultur aparatur yang menjadi patologi dalam pelaksanaan birokrasi seperti termuat dalam toha , 2008 : 109 yang menyatakan bahwa SDM aparatur tengah terlena dengan budaya birokrasi lama dimana prinsip kerja asal bapak senang, kultur yang membiasakan memberikan kelonggaran terhadap maraknya ketidakjujuran, korupsi dan suka tidak menghargai serta tidak mematuhi hukum. Sistem laporan kebut semalam atau copy paste kegiatan sebelumnya, program - program yang money oriented, sikap ingin dilayani bukan melayani dan berbagai permasalahan lainnya berkaitan dengan SDM aparatur yang perlu diteliti lebih jauh seiring dengan telah diimplementasikannya kebijakan reformasi birokrasi ini.

Berpedoman pada road map reformasi birokrasi kota payakumbuh tahun 2016 - 2020 menyebutkan bahwa persoalan reformasi birokrasi bidang SDM aparatur adalah belum proporsional dan belum profesionalnya ASN di kota Payakumbuh. SDM aparatur yang ada mulai dari pemangku jabatan hanya mengisi kekosongan posisi yang ada, pelaksana di meja pelayanan yang bertatap muka langsung dengan masyarakat hanya bekerja formal namun tidak mengetahui bahwasanya saat ini mereka sedang berada dalam tahapan reformasi birokrasi dan tidak paham dengan ukuran keberhasilannya dikuatkan oleh evaluasi KemenpanRB tahun 2019 bahwasanya dari pegawai yang disurvey sebanyak $8 \%$ tidak mengetahui sama sekali tugas fungsi dan ukuran keberhasilan pekerjaan yang dilaksanakan sedangkan 67 $\%$ paham tugas dan fungsi namun tidak mengetahui ukuran keberhasilannya dan hanya $25 \%$ saja yang mengetahui tugas fungsi dan ukuran keberhasilannya. Hal ini seharusnya menjadi prioritas untuk dibenahi jika berlarut tentu saja dapat berdampak pada tidak maksimalnya kinerja birokrasi dan percepatan pelaksanaan reformasi birokrasi menjadi terhambat, karena perubahan birokrasi dapat terjadi jika dimulai dari SDM aparaturnya sendiri,Jika aparatur diam di tempat tanpa perubahan maka akan tertinggal kareana perubahan birokrasi mutlak terjadi bahkan dibutuhkan untuk penyesuaian terhadap perkembangan/perubahan global yang terjadi (Mulyadi, $2018: 130$ ) 


\section{METODE}

Data-data hasil wawancara, diolah dan dianalisis menggunakan analisa data kualitatif. Menganalisis data, berarti secara sistematis menyusun, mengintegrasikan, dan menyelidiki data menjadi akurat dan dapat bersifat informastif. Merujuk pada Neuman (2013), menganalisa data kualitatif berbeda dengan analisa data kuantitatif yang baru bisa dilakukan setelah pengumpulan data, analisa data kualitatif sudah dapat dilakukan ketika proses pengumpulan data dilakukan.

\section{HASIL DAN PEMBAHASAN}

Focus dari riset ini adalah area perubahan bidang SDM Aparatur dimana hasil yang diharapkan dengan dilaksanakannya reformasi birokrasi bidang SDM aparatur adalah untuk menghasilkan :

a. SDM aparatur yang berintegritas

b. SDM aparatur yang netral baik dalam politik ataupun dalam pelayanan publik.

c. SDM aparatur yang kompeten sehingga bisa ditempatkan diposisi apapun

d. SDM aparatur capable atau mampu menyelesaikan beban tanggung jawab pekerjaan yang diberikan

e. SDM Aparatur yang profesional sehingga mendahulukan kepentingannya sebagai ASN daripada kepentingan pribadi

f. SDM Aparatur yang berkinerja tinggi

g. SDM Aparatur yang menyejahterakan masyarakat yang dilayaninya.

SDM Aparatur yang bekerja pada pemerintah kota payakumbuh pada November 2020 berjumlah 3001 Orang. Terdiri dari 967 orang laki laki dan 2.034 orang perempuan yang tersebar pada dinas sebanyak 593 orang laki laki dan 1.635 orang perempuan total 2.278 orang, di unit kerja badan sebanyak 286 orang terdiri dari 151 orang laki laki dan 135 orang perempuan, pada kantor jumlah SDM Aparatur adalah 12 orang terdiri dari 6 laki laki dan 6 perempuan serta di kecamatan dan kelurahan sebanyak 314 orang terdiri dari 158 orang laki laki dan 156 orang perempuan. Usia SDM aparatur terbanyak adalah di usia 40-44 tahun dan pendidikan mereka terbanyak di jenjang strata satu.

Dalam jabatan masih terdapat beberapa posisi kosong, hal ini dikarenakan ada pejabat yang sudah memasuki usia pensin sehingga untuk pengisian kembali jabatan harus berdasarkan rapat tim dan untuk jabatan tinggi akan dilakukan lelang terbuka. Dari 7 (tujuh) indikator hasil yang diinginkan dari implementasi kebijakan reformasibirokrasi area perubahan SDM aparatur dapat disimpulkan sebagai berikut :

\section{A. SDM aparatur yang berintegritas}

SDM Aparatur yang berintegritas berdasarkan amanat Permenpan Nomor 60 tahun 2020 berarti SDM aparatur yang konsisten berperilaku yang selaras dengan nilai, norma dan/atau etika organisasi, dan jujur dalam hubungan dengan atasan, rekan kerja, bawahan langsung, dan pemangku kepentingan, serta mampu mendorong terciptanya budaya etika tinggi, bertanggung jawab atas tindakan atau keputusan beserta risiko yang menyertainya.

Integritas seorang individu dapat diukur dengan :

- kejujuran,

- kepatuhan terhadap ketentuan peraturan perundang-undangan,

- kemampuan bekerja sama, serta

- pengabdian kepada masyarakat, bangsa dan negara. 
Integritas di Kota Payakumbuh sudah terlihat sangat baik terlihat dari dilaksanakannya arahan dari pimpinan oleh aparatur dibawahnya dengan sangat baik terlihat dari kepatuhan, disiplin dan pengabdian yang dilakukan SDM aparatur terhadap tanggungjawabnya kepada masyakat dan Negara.

\section{B. SDM aparatur yang netral baik dalam politik ataupun dalam pelayanan publik.}

Netralitas ASN meliputi netralitas dalam Pelayanan Publik, netralitas dalam politik, netralitas dalam membuat kebijakan dan netralitas dam manajemen Aparatur.

Netralitas SDM Aparatur di Kota Payakumbuh terlihat juga sudah baik terbukti dari informasi bawaslu bahwasanya belum ada data pelanggaran yang dilakukan SDM aparatur terkait politik dan pemilihan gubernur serentak yang akan diadakan tanggal 9 desember 2020 nanti, Kemudian dalam pelayanan public juga sudah baik dilihat dari penilaian masyarakat terhadap kepuasan pelayanan yang diadakan oleh pemerintah kota payakumbuh yang sangat baik. Netralitas dalam manajamen aparatur juga baik karena penerimaan CPNS dilakukan sudah system transparan dan lelang jabatan tinggi juga dilaksanakan terbuka, dalam membuat kebijakan oleh pimpinan terkait juga baik karena saat ini pimpinan sangat tegas jika ada pengaduan masyarakat atau kinerja buruk maka pimpinan tidak segan merotasi atau memutasi SDM aparatur, sehingga hal ini tentu saja membuat SDM aparatur harus lebih berhati hati dalam bekerja, melayani masyarakat dan menggunakan anggaran.

\section{SDM aparatur yang kompeten sehingga bisa ditempatkan diposisi apapun}

kompetensi SDM aparatur terdiri dari 3 bagian yakni :

a. Kompetensi Teknis adalah pengetahuan, keterampilan, dan sikap/perilaku yang dapat diamati, diukur dan dikembangkan yang spesifik berkaitan dengan bidang teknis jabatan.

b. Kompetensi Manajerial adalah pengetahuan, keterampilan, dan sikap/perilaku yang dapat diamati, diukur, dikembangkan untuk memimpin dan/atau mengelola unit organisasi.

c. Kompetensi Sosial Kultural adalah pengetahuan, keterampilan, dan sikap/perilaku yang dapat diamati, diukur, dan dikembangkan terkait dengan pengalaman berinteraksi dengan masyarakat majemuk dalam hal agama, suku dan budaya, perilaku, wawasan kebangsaan, etika, nilai-nilai, moral, emosi dan prinsip, yang harus dipenuhi oleh setiap pemegang Jabatan untuk memperoleh hasil kerja sesuai dengan peran, fungsi dan Jabatan.

Untuk Kompetensi yang dimiliki oleh SDM aparatur pada umumnya mengatakan bahwa tidak pernah mendapatkan pelatihan yang didakan berkaitan dengan bidang teknis tempatnya bekerja, kecuali untuk bidang keuangan. Diklat keuangan banyak dan rutin diadakan oleh pemerintah dikarenakan setiap tahunnya penyelenggaraan pengelolaan keuangan harus disesuaikan dengan berbagai system dan aplikasi yang ada, sehingga tidak dimungkinkan jika tidak dilaksanakan diklat. Akan tetapi untuk bidang lain kompetensi teknis ataupun manajerial jarang diadakan bahkan untuk tahun ini tidak ada dilaksanakan dan untuk tahun depan juga tidak ada dianggarkan dianggarkan dana dialihkan ke penanganan pandemic covid -19 .

\section{D.SDM aparatur capable atau mampu menyelesaikan beban tanggung jawab pekerjaan yang diberikan}

Capable berarti kemampuan, sedangkan kemampuan Kerja seseorang akan ditentukan oleh tinggi rendahnya tingkat pendidikan dan pengalaman. Karena kedua unsur inilah pengetahuan dan keterampilan dapat diperoleh. Jadi semakin tinggi tingkat pendidikan seseorang ditunjang dengan adanya pengalaman yang luas menunjukkan orang tersebut mempunyai tingkat kemampuuan yang tinggi. Selain tingkat pendidikan dan pengalaman untuk meningkatkan kemampuan seseorang dapat ditempuh melalui pendidikan dan pelatihan, karena dengan adanya pendidikan dan pelatihan akan menambah pengetahuan 
seseorang untuk mengerjakan sesuatu bisa menjadi lebih cepat dan lebih baik.(Mesina Yoman dkk Jurnal administrasi publik No.03 vol.040 2016)

Aparatur dengan pendidikan S1 adalah terbanyak di Kota Payakumbuh. Akan tetapi dari hasil penelurusan saya dengan mewawancara mereka banyak dari mereka yang bekerja tidak sesuai dengan latar belakang pendidikan mereka.SDM aparatur yang bekerja pada satu jabatan hanya dibebankan pada rencana kerja yang dibuat tanpa memandang latar belakang pendidikannya

\section{E. SDM Aparatur yang professional sehingga mendahulukan kepentingannya sebagai ASN daripada kepentingan pribadi}

Profesionalisme dari aparatur negara menjadi lemah dikarenakan kapabilitas dan kompetensi dari SDM aparatur. Secara umum penghargaan banyak diterima oleh kota payakumbuh dikarenakan terpenuhinya indikator indikator penunjang keberhasilan dari suatu ajang yang diadakan, akan tetapi hal itu belumlah dirasakan secara menyeluruh oleh setiap individu aparatur. Akan tetapi dengan komitmen yang nyata dan serius dari pejabat politiknya membuat seluruh lini di pemerintahan kota payakumbuh berpacu untuk meningkatkan kinerja dan pelayanan. Karena perwujudan dari visi yang dituangkan pada saat kampanye menyangkut kepentingan masyarakat lebih diutamakan oleh Pimpinan yang berkuasa saat ini. Anggaran untuk peningkatan kapabilitas dan kompetensi pegawai memang minim dianggarkan.

\section{F.SDM Aparatur yang berkinerja tinggi}

Kinerja SDM Aparatur dipayakumbuh ditunjukkan dengan penyampaian laporan e - kinerja melalui system dan aplikasi yang ada setiap harinya. Dan hal tersebut menjadi dasar bagi dibayarkannya tunjangan finansial yakni tunjangan kinerja, sehingga setiap SDM aparatur berlomba lomba untuk meningkatkan kinerjanya.

Pesatnya perkembangan teknologi berdampak pada pelaksanaan tugas dan fungsi pemerintahan dengan pemanfaatan teknologi, khususnya teknologi digital. Transformasi pelaksanaan pengelolaan pemerintahan dari klasik menjadi e-government juga sudah diterapkan di Kota Payakumbuh. Saat ini sudah dilaksanakan e-budgeting, SPBE, work from home, one single submission, whistle blowing dan digitalisasi lainnya. Tantangan global menuntut para eksekutif untuk cakap dan respon dalam menjalankan proses-proses pelayanan pemerintahan berbasis digital atau elektronik. Isu ini menjadi penting untuk direspon dalam merumuskan langkah strategis untuk mewujudkan pemerintahan kelas dunia di tahun 2025. Dalam hal ini, pemerintah daerah harus melakukan transformasi digital melalui pelaksanaan tata kelola elektronik yang terpadu dalam rangka mendukung transformasi proses bisnis pemerintahan untuk mewujudkan layanan mandiri, layanan bergerak dan layanan cerdas yang fleksibel dan tanpa batas.

Kota Payakumbuh Dibawah kepemimpinan bapak Reza falepi menggenjot Aparaturnya untuk berlomba lomba menciptakan inovasi inovasi yang digunakan oleh masyarakat. Dalam pemberian pelayanan pun juga sekarang tidak menunggu di kantor tetapi pelayanan jemput bola contohnya pada dinas capil yang melakukan pendataan terhadap anak - anak yang berumur 17 tahun kesekolah untuk langsung dibuatkan KTP elektronik serta bekerja sama dengan pihak rumah sakit dimana jika ada kelahiran langsung dibuatkan akte kelahirannya.

\section{G.SDM Aparatur yang menyejahterakan masyarakat yang dilayaninya}

Berdasarkan amanat undang undang no 5 tahun 2014 kompensasi terbagi kepada 2 yakni kompensasi financial dan kompensasi non financial. Kompensasi finasial berupa gaji, dan tunjangan sedangkan kompensasi non financial berupa fasilitas, penghargaan, pengembangan kompetensi, Jaminan pensiun, jaminan hari tua, perlindungan (kesehatan, kecelakaan kerja), dll. Ketentuan penggajian diatur dalam UU ASN pasal 79 tahun 2014. Adapun tujuan dari diberikannya kompensasasi terhadapat 
Aparatur adalah untuk mempengaruhi perilaku pegawai dan mendorong capaian kinerja organisasi serta menarik dan mempertahankan kandidat yang memiliki kualifikasi tinggi agar dapat bergabung dengan organisasi dan melaksanakan tugas yang dibutuhkan organisasi

Tingkat kesejahteraan SDM aparatur di Kota Payakumbuh sudah mengikuti aturan dari pusat. Tunjangan daerah yang diberikan juga sudah disesuaikan dengan PAD kota Payakumbuh. Akan tetapi pada umumnya SDM Aparatur sudah menjaminkan SK nya di Bank sehingga penghasilan financial yang diterima menjadi sedikit dan berupaya mencari tambahan lain diluar kantor.

\section{KESIMPULAN}

Secara umum pelaksanaan reformasi birokrasi area perubahan SDM aparatur pemerintah kota payakumbuh sudah berjalan dengan sangat baik di Kota Payakumbuh. Hal ini diketahui dari hasil yang diinginkan dari diimplementasikannya kebijakan reformasi birokrasi yakni untuk indikator integritas sudah sangat baik dilihat dari sudah bekerjanya SDM aparatur dengan memegang teguh prinsip bekerja secara jujur dan bertanggung jawab, dari netralitas juga sudah sangat baik karena dari infomasi bawaslu belum ada pelanggaran yang dilakukan Aparatur serta dalam pelayanan juga netral terlihat dari kepuasan masyarakat yang menerima layanan merasa diperlakukan sama, untuk kompeten memang terlihat masih kurang karena sdm aparatur tidak ditempatkan sesuai dengan latar belakang pendidikannya kemudian dari indikator kapabilitas juga kurang karena masih banyak sdm aparatur dengan tingkat pendidikan yang masih rendah, dikarenakan kompetensi dan kapabilitas yang kurang menyebabkan untuk indikator profesionalitas menjadi lemah karena berkaitan dengan kompetensi dan kapabilitas sdm aparaturnya yang masih kurang tersebut, namun secara organisasi sudah baik karena memenuhi standar evaluasi dari berbagai evaluasi dan pengawasan yang diadakan dibuktikan dengan banyaknya penghargaan yang diterima Kota Payakumbuh untuk indikator selanjutnya yakni berkinerja tinggi, SDM aparatur yang bekerja menerima dan menjalankan instruksi dari pimpinannya,mematuhi ketentuan yang berlaku sedangkan untuk pemimpin juga sangat baik dalam mengarahkan dan menginstruksikan kebijakan sehingga membawa perubahan yang cukup signifikan dalam pelaksanaan birokrasi pemerintah. Tunjangan kinerja yang diberikan juga didasarkan atas kinerja yang ditunjukkan oleh SDM aparaturnya setiap hari melalui laporan e-kinerja setiap harinya pada aplikasi yang disediakan membuat aparatur berlomba lomba untuk menampilkan kinerja yang maksimal dan terbaik.Dan indikator terakhir adalah sejahtera, untuk indicator kesejahteraan SDM aparatur terlihat dari penghasilan financial yang diterima SDM aparatur dilaksanakan sudah mengikuti arahan pusat ditambah dengan tunjangan kinerja dan tunjangan lain sesuai jabatan masing masing.

Berdasarkan pembahasan dapat disarankan untuk mengaplikasikan suatu program atau kebijakan memang semestinya timbul dari kesadaran dan komitmen yang kuat dari pimpinan dan aparatur dibawahnya untuk mencapai sasaran yang direncanakan. Sehingga dengan sinergitas antara pimpinan dan aparatur yang bekerja akan tercipta saling mempercayai bahwa tugas dan tanggung jawab mulia

\section{DAFTAR PUSTAKA}

[1] Amy Y.S Rahayu, Vishnu Juwono. 2018. Birokrasi \& Governance. Depok : Rajawali Pers

[2] Hasibuan, Malayu. 2001. Manajemen Sumber Daya Manusia. Jakarta: PT Bumi. Aksara.

[3] Lubis, S.B.Hari dan Hussaini, Martani 2009. Pengantar teori organisasi suatu pendekatan makro. Departemen ilmu administrasi fakltas ilmu sosial dan ilmu politik universitas Indonesia 
[4] Muyadi, Deddy (2018). Perilaku organisasi dan kepemimpinan pelayanan. Alfabeta.Bandung

[5] Neuman, W. Lawrence. 2013 . Metodologi Penelitian Sosial: Pendekatan Kualitatif dan Kuantitatif Edisi 7. Indeks : Jakarta

[6] Rudito, Bambang dkk 2016. Aparatur Sipil Negara pendukung reformasi birokrasi.Kencana:Jakarta

[7] Thoha, Miftah. (2011). Birokrasi Pemerintah Indonesia di Era Reformasi. Jakarta: Kencana Prenada Media Group.

[8] Winardi, J.2005. Manajemen Perubahan (Management of Change). Prenada Media. Jakarta

[9] Weber, M. (2009). Terjemahan. Yogyakarta: Pustaka Pelajar.

[10] Widjaja. (2011). Otonomi Daerah dan Daerah Otonom. Jakarta: PT. Raja Grafindo Persada.

[11] Wiranto, Singgih. 2004. Pengawasan Represif Terhadap Peraturan Daerah dan Keputusan Kepala Daerah Berdasarkan Undang-Undang Nomor 22 Tahun 1999 tentang Pemerintahan Daerah. Program Pascasarjana Universitas Gadjahmada. Yogyakarta

[12] Yoman dkk Jurnal administrasi publik No.03 vol.040 2016

[13] Peraturan Presiden Nomor 81 Tahun 2010 tentang Grand Design Reformasi Birokrasi 2010-2025

[14] Undang-Undang Nomor 5 Tahun 2014 tentang Aparatur Sipil Negara

[15] Bezzeting BKPSDM Kota Payakumbuh Periode November 2020 